\title{
First adult record of Misgurnus anguillicaudatus, Cantor 1842 from Ribeira de Iguape River Basin, Brazil
}

\author{
Primeiro registro de um indivíduo adulto de Misgurnus anguillicaudatus, \\ Cantor 1842 do rio Ribeira de Iguape, Brasil
}

Caio Isola Dallevo do Amaral Gomes ${ }^{1}$, Alexandre Peressin ${ }^{2}$, Mauricio Cetra ${ }^{3}$ and Walter Barrella ${ }^{4}$

${ }^{1}$ Departamento de Ciências Biológicas, Universidade Federal de São Carlos - UFSCar, Rod. João Leme dos Santos, Km 110, CEP 18052-780, Sorocaba, SP, Brazil e-mail: caioisola@yahoo.com.br

${ }^{2}$ Programa de Pós-Graduação em Diversidade Biológica e Conservação,

Universidade Federal de São Carlos - UFSCar, Rod. João Leme dos Santos, Km 110,

CEP 18052-780, Sorocaba, SP, Brazil

e-mail: alex_peressin@yahoo.com.br

${ }^{3}$ Departamento de Ciências Ambientais, Universidade Federal de São Carlos - UFSCar, Rod. João Leme dos Santos, Km 110, CEP 18052-780, Sorocaba, SP, Brazil e-mail: mcetra@ufscar.br

${ }^{4}$ Laboratório de Ecossistemas Aquáticos, Pontifícia Universidade Católica de São Paulo - PUC-SP, Sorocaba, SP, Brazil e-mail: vbarrella@pucsp.br

\begin{abstract}
Aim: This work aimed to describe a first record of Misgurnus anguilicaudatus, Cantor 1842 in São Paulo state, as well as your potential impacts on native populations. Methods: The specimen was caught by eletro-fishing device, in Itaguapeva river, Ribeira do Iguape river basin, Ibiuna (SP), Brazil. Later, it was fixed in $10 \%$ formalin and taken to laboratory for species identification, morphometric data evaluation, diet analysis and stage of gondal maturity. Results: The individual was an adult female, without parasites and with gonads in maturity stage $B$, which indicates vascularized ovaries and presence of oocytes in vitellogenesis process. The dietary analysis showed that $95.3 \%$ of the stomach was occupied by insect larvae. Conclusions: The diet analysis may suggest food overlap and consequent competition for food with native species of the genera Trichomycterus e Characidium, which consume essentially the same items. Still, the great morphological similarity with native species, especially Siluriformes, could generate competition for shelters. Additionally, the stage of gonadal maturity and a recorded ability of the species on establish invasive populations in different environments raise concerns about the possibility of Misgurnus anguillicaudatus reproduction on the studied site.
\end{abstract}

Keywords: oriental weatherfish, exotic species, sexual maturity, diet overlap, São Paulo State.

Resumo: Objetivo: Este trabalho objetivou descrever o primeiro registro de Misgurnus anguillicaudatus, Cantor 1842 no estado de São Paulo, bem como seus potenciais impactos em populaçóes nativas. Métodos: $\mathrm{O}$ exemplar foi capturado com equipamento de pesca elétrica, no Rio Itaguapeva, bacia hidrográfica do Rio Ribeira de Iguape, no Município de Ibíuna (SP), Brasil. Posteriormente, foi fixado em formalina 10\% e levado ao laboratório, para identificação da espécie, coleta de dados morfométricos, avaliação do estádio de maturidade gonadal (Vazzoler, 1996) e análise do conteúdo estomacal. Resultados: O indivíduo capturado era uma fêmea adulta, sem parasitas e com gônadas em estádio de maturidade $\mathrm{B}$, que indica ovários já vascularizados e presença de ovócitos em processo de vitelogênese. A análise da dieta revelou que 95,3\% do estômago era ocupado por larvas de insetos. Conclusóes: A composição da dieta pode sugerir sobreposição alimentar e conseqüente competição por alimento com espécies nativas dos gêneros Trichomycterus e Characidium, que consomem essencialmente os mesmo itens. Ainda, a grande semelhança morfológica com espécies nativas, principalmente Siluriformes, poderia gerar disputa por abrigos. Adicionalmente, o estádio de maturidade gonadal e a já registrada capacidade da espécie de estabelecer populaçóes invasoras em diversos ambientes geram preocupaçóes quanto à possibilidade de reprodução da espécie no local.

Palavras-chave: Dojo, espécies exóticas, maturidade sexual, sobreposição de dieta, Estado de São Paulo. 


\section{Introduction}

The oriental weatherfish, Misgurnus anguillicaudatus Cantor, 1842, know in Brazil as Dojo, is a member of the Cobitid family, wich is very popular among aquarists including species such as the clown loach Chromobotia macracanthus (Bleeker, 1852), yoyo loach Botia lohachata Chaudhuri, 1912 and the kuhli loach Pangio kublii (Valenciennes, 1846). The dojo diet consists in worms, crustaceans, insect larvae and adult insects; it can reach $28 \mathrm{~cm}$ length, and support temperatures from 2 to $28{ }^{\circ} \mathrm{C}$ (Allen et al., 2002). In addition, the species has the ability to breathe atmospheric air for short periods due to adaptations of the respiratory system (Gonçalves et al., 2007). These characteristics allow its incidence in a wide range of environments such as streams, ponds, lakes, estuaries and swamps, giving preference to lentic environments (Freyhof and Korte, 2005; Franch et al., 2008). The spawning period occurs between May and August (Fujimoto et al., 2008).

Information on the ecological and socioeconomical impact of fish introductions are scarce, and even in documented cases it is not given enough emphasis (Casal, 2006). Currently, there are reports of consolidated populations of $M$. anguillicaudatus introduced in the United States, Germany, Italy, Spain, Palau, Indonesia, Australia and the Philippines (Freyhof and Korte, 2005). In the USA, the first invasive populations were recorded in the decade of the 1930s (Freyhof and Korte, 2005), and they already demonstrate an established association with native macrophytes as hideouts (Tabor et al., 2001). In Europe the first record of a population was made in Italy in 1990 and in Germany this occurred 14 years after the first record of an individual specimen made in 1990 (Freyhof and Korte, 2005). A study demonstrating the establishment of the species in the Ebro Delta River, in Spain, reports the capture of more than 1000 individuals, adults and juveniles, in less than 7 years (Franch et al., 2008). In Brazil four individuals were caught in a stream in the Paraná River Basin between 2000 and 2001 (Ingenito et al., 2004) and several individuals were reported to the middle and high part of the Iguaçu River (Vitule, 2009). According to Oyakawa and Menezes (2011), there are no records of this species in the state of São Paulo. Nowadays, M. anguillicaudatus is imported for ornamental use in aquariums. However, the species was introduced as food source and living baits in the United States, Australia and Turkmenistan (Freyhof and Korte, 2005).

\section{Material and Methods}

The specimen was captured in 2010 in the Itaguapeva River, a tributary of the Ribeira de Iguape River Basin, São Paulo (47 14'36" S and $\left.23^{\circ} 51^{\prime} 46^{\prime \prime} \mathrm{W}\right)$ (Figure 1). The stream is located on a well preserved mountain area, where a rich vegetation coverage occurs. There is no underwater vegetation but the presence of rocks and logs provides a great amount of shelters.

\section{Results}

The specimen captured (Figure 2) was fixed in a $10 \%$ formaldehyde solution, identified (Kottelat et al., 1998) and included in the fish collection of the laboratory of ecology of stream fish of the UFSCar-Sorocaba. It was a female measuring $15.3 \mathrm{~cm}$ (ST) and weighting $12.84 \mathrm{~g}$. Since the individual was more than $8 \mathrm{~cm}$ in standard length, it was classified as an adult (Fujimoto et al., 2008). The body proportions of the specimen captured was in agreement with morphometrics traits of M. anguillicaudatus (Park et al., 2006) (Table 1).

\section{Discussion}

The large size of the specimen can be associated to introduction by aquarists. Fish release by aquarists can be aggravated when the animals are close to the sexual maturity, facilitating a successful establishment of a new population (Duggan et al., 2006). This is consistent with our observations because the female presented gonads in the B state

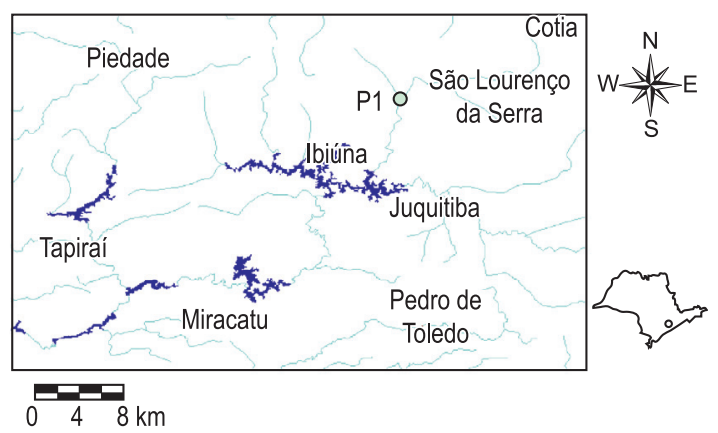

Figure 1. The study area with the sampling site (P1) in the Itaguapeva River (SINBIOTA, 2011).

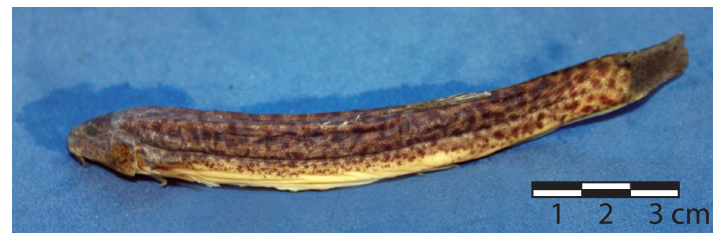

Figure 2. The specimen captured. 
Table 1. Comparisons between body proportions of $M$. anguillicaudatus obtained by us and by Park et al. (2006). All measures were made in $\mathrm{mm}$. DSA = distance between snout and origin of anal fin; DSP $=$ distance between snout and origin of pelvic fin; DPA = distance between origin of pelvic fin and origin of anal fin; $\mathrm{HL}=$ head length; DPP = distance between origin of pectoral fin and origin of pelvic fin; $\mathrm{CPL}=$ caudal peduncle length; $\mathrm{CPD}=$ caudal peduncle depth; $\mathrm{BD}=$ body depth; DED = distance between snout and origin of dorsal fin; LD = length of dorsal fin base; LB = length of third barbell; ED = eye diameter; SNL = snout length; $\mathrm{SL}=$ standard length.

\begin{tabular}{lcc}
\hline Ratio $(\%)$ & $\begin{array}{c}\text { Specimen } \\
\text { captured }\end{array}$ & $\begin{array}{c}\text { Park et al. (2006) } \\
\text { (Mean } \pm \text { SD) }\end{array}$ \\
\hline DSA to SL & 73.28 & $73.7 \pm 1.9$ \\
DSP to SL & 60.03 & $60.2 \pm 2.2$ \\
DPA to SL & 15.08 & $14.3 \pm 1.0$ \\
HL to SL & 17.02 & $16.9 \pm 1.1$ \\
DPP to SL & 42.08 & $42.4 \pm 1.4$ \\
CPL to SL & 15.45 & $14.3 \pm 1.3$ \\
CPD to SL & 9.3 & $9.4 \pm 0.7$ \\
BD to SL & 12.2 & $11.8 \pm 0.6$ \\
DED to SL & 59.11 & $57.2 \pm 2.9$ \\
LD to SL & 9.09 & $10.3 \pm 1.2$ \\
CPD to CPL & 60.36 & $58.0 \pm 1.6$ \\
LB to HL & 33.21 & $37.4 \pm 2.2$ \\
ED to HL & 15.48 & $15.8 \pm 1.5$ \\
SNL to HL & 38.58 & $42.3 \pm 3.1$ \\
\hline
\end{tabular}

of maturity (Vazzoler, 1996). This means there were various ovocites in the first stages of vitolegenesis and the gonads were vascularized, suggesting the possibility of sexual maturity and spawning.

The diet overlap is another possible impact of the establishment of this species in the environment. About $96 \%$ of the stomach content of the specimen was composed by insect larvae and the remaining items were fragments of adult insects. Species of the genera Characidium and Trichomycterus, which are native taxa of the Itaguapeva river, feed on the same items found in the stomach of $M$. anguillicaudatus (Rondineli et al., 2009). Thus, the invasive species can be a potential competitor with the native ones.

We found a morphological similarity between the $M$. anguillicaudatus and the Trichomycterus species. Both fish have elongated and thin bodies, equipped with well developed barbells, indicating a putative competition by natural shelter.

Although no parasite has been found on the specimen collected, records about the presence of this ecological relation in introduced populations and the known cases in which parasites coming from exotic species spread to local ones suggests precaution on this aspect (Dove and Ernst, 1998, Leal et al., 2010).

The wide range of possible impacts here demonstrated emphasizes the importance of creating awareness in the population about the environmental and socioeconomic impacts derived from the introduction of exotic species into the environment, coming to the conclusion that euthanasia is a better option than the release into the wild.

\section{Acknowledgements}

We acknowledge FAPESP (PROC 2009/53056-8) for the financial support to carry out this research.

\section{References}

ALLEN, GR., MIDGLEY, SH. and ALLEN, M. 2002. Field guide to the freshwater fishes of Australia. Perth: Western Australian Museum.

CASAL, CMV. 2006. Global documentation of fish introductions: the growing crisis and recommendations for action. Biological invasions, vol. 8, p. 3-11. http://dx.doi.org/10.1007/s10530005-0231-3

DOVE, ADM. and ERNST, I. 1998. Concurrent invaders - four exotic species of Monogenea now established on exotic freshwater fishes in Australia. International Journal for Parasitology, vol. 28, p. 1755-1764. http://dx.doi.org/10.1016/S00207519(98)00134-9

DUGGAN, IC., RIXON, CAM. and MACISAAC, HJ. 2006. Popularity and propagule pressure: determinants of introduction and establishment of aquarium fish. Biological invasions, vol. 8, p. 377-382. http://dx.doi.org/10.1007/s10530-004-2310-2

FRANCH, N., CLAVERO, M., GARRIDO, M., GAYA, N., LOPEZ, V., POU-ROVIRA, Q. and QUERAL, JM. 2008. On the establishment and range expansion of oriental weatherfish (Misgurnus anguillicaudatus) in NE Iberian Peninsula. Biological Invasions, vol. 10, p. 1327-1331. http://dx.doi.org/10.1007/s10530007-9207-9

FREYHOF, J. and KORTE, E. 2005. The fisrt record of Misgurnus anguillicaudatus in Germany. Journal of Fish Biology, vol. 66, p. 568-571. http://dx.doi. org/10.1111/j.0022-1112.2005.00606.x

FUJIMOTO, Y., OUCHI, Y., HAKUBA, T., CHIBA, H. and IWATA, M. 2008. Influence of modern irrigation, drainage system and water management on spawning migration of mud loach, Misgurnus anguillicaudatus C. Environmental Biology of Fishes, vol. 81, p. 185-194. http://dx.doi.org/10.1007/ s10641-007-9188-7 
GONÇALVES, AF., CASTRO, LFC., PEREIRAWILSON, C., COIMBRA, J. and WILSON, JM. 2007. Is there a compromise between nutrient uptake and gas exchange in the gut of Misgurnus anguillicaudatus, an intestinal air-breathing fish? Comparative Biochemistry and Physiology, vol. 2, part D, p. 45-355.

INGENITO, LFS., DUBOC, LF. and ABILHOA, V. 2004. Contribuiçáo ao conhecimento da ictiofauna da bacia do alto rio Iguaçu, Paraná, Brasil. Arquivos de Ciências Veterinárias e Zoologia UNIPAR, vol. 7, no. 1, p. 23-36.

KOTTELAT, M. 1998. Fishes of the Nam Theun and Xe Bangfai basins, Laos, with diagnoses of twenty-two new species (Teleostei: Cyprinidae, Balitoridae, Cobitidae, Coiidae and Odontobutidae). Ichthyological Exploration of Freshwaters, vol. 9, no. 1, p. 1-128.

LEAL, ME., KLEIN, GF., SCHULZ, UH. and LEHMANN, PA. 2010. Primeiro registro e aspectos ecológicos de Hoplerythrinus unitaeniatus (Agassiz, 1829) (Characiformes, Erythrinidae) como espécie introduzida na Bacia do Rio dos Sinos, RS, Brasil. Biota Neotropica, vol. 10, no. 3. Available from: <http://www.biotaneotropica.org.br/v10n3/pt/abstr act?article+bn00710032010 .

OYAKAWA, OT. and MENEZES, NA. 2011. Checklist of fresh water fishes from São Paulo State, Brazil. Biota Neotropica, vol. 11, no. 1a. Available from: $<$ http://www.biotaneotropica.org.br/v11n1a/en/abs tract?inventory+bn0021101a2011>.
PARK, IS., NAM, YK. and KIM, DS. 2006. Growth performance, morphometric traits and gonad development of induced reciprocal diploid and triploid hybrids between the mud loach (Misgurnus mizolepis Gunther) and cyprinid loach (Misgurnus anguillicaudatus Cantor). Aquaculture Research, vol. 37, p. 1246-1253. http://dx.doi. org/10.1111/j.1365-2109.2006.01556.x

RONDINELI, GR., CARMASSI, AL. and BRAGA, FMS. 2009. Population biology of Trichomycterus sp. (Siluriformes, Trichomycteridae) in Passa Cinco stream, Corumbataí River sub-basin, São Paulo State, southeastern Brazil. Brazilian Journal of Biology, vol. 69, no. 3, p. 925-934. PMid:19802454.

Sistema de Informação Ambiental do Biota SINBIOTA. 2011. Atlas Biota. Biota, Fapesp. Avaliable from: <http://www.biota.org.br/mapcria>. Access in: 25 nov. 2011.

TABOR, RA., WARNER, E. and HAGER, S. 2001. An Oriental weatherfish (Misgurnus anguillicaudatus) population estabilished in Washington State. Northwest Science, vol. 75, no. 1, p. 72-76.

VAZZOLER, AEAM. 1996. Biologia da reprodução de peixes teleósteos: teoria e prática. Maringá: EdUEM. 169 p.

VITULE, JRS. 2009. Introdução de peixes em ecossistemas continentais brasileiros: revisão, comentários e sugestôes de açôes contra o inimigo quase invisível. Neotropical Biology and Conservation, vol. 4, no. 2, p.111-122.

Received: 06 July 2011 Accepted: 14 December 2011 